\title{
The effect of mercury, quintozene and thiophanate-methyl on the yield of winter rye at the Kotkaniemi experimental farm during the years $1972-1978$
}

JUHANI UOTI

Kemira Oy, PL 330, 00101 Helsinki 10.

\begin{abstract}
The spraying of the seedlings in the autumn with thiophanate-methyl gave the highest yield increase when there was snowmould present. In most cases the yield increase was obtained even in the absence of the disease. Seeddressing with this product also appeared very beneficial. The results of quintozene-spraying and mercuryseeddressing were not as good. The difficulty of finding the correct timing for quintozenespraying limits its efficiency in practice.
\end{abstract}

\section{Introduction}

The survival of autumn sown cereal crops is dependent on several different factors. In southern Finland the major fungus problem is Fusarium nivale (Fr.) Ces. which causes snowmould or pink snowmould (Jamalainen 1956). The role of other Fusarium species, especially that of F. culmorum (W. G. Sm.) Sacc. in causing the same disease remains to be established. The studies of MÄKELÄ (1978) have shown its abundance in the seedlings of winter crops both in the autumn and in the spring. In some years also abiotic factors, such as severe frost on snowless ground, alternating freezing and melting of the ice during the end of the winter, and cold, dry winds in the early spring, are responsible for the poor stands of winter wheat and rye.

The resistance or susceptibility of winter cereals to winter killing fungi is very much dependent on the variety (JAmalainen 1969). Chemical control is, however, always useful, because in severe conditions even resistant varieties often suffer considerable damage. Seeddressing with mercury and the spraying of the seedlings with quintozene has been shown to be beneficial in numerous trials carried out by JAMALAINEN $(1962,1964)$, and are presently commonly used by the farmers (TIITTANEN and Blomvist 1978).

Thiophanate-methyl has been only recently officially registered for the seeddressing or the seedling spraying of winter cereals. In the trials during the successive years of $1972-1978$ at the Kotkaniemi experimental farm near Helsinki its efficacy was compared to that of mercury and quintozene. 


\section{Material and methods}

\section{Seeddressing trials}

The Finnish rye varieties Voima, in 1972-1977, and Aitta, in 1978, were treated with $200 \mathrm{~g} / 100 \mathrm{~kg}$ seed with Täyssato, a commercial mercury product (methoxyethyl-mercury-chloride $22.1 \mathrm{~g} / \mathrm{kg}$ ) and with Topsin M, a commercial thiophanate methyl product $(700 \mathrm{~g} / \mathrm{kg})$, both as powder formulations. The treated seed was sown with a normal tractor-driven drill $190 \mathrm{~kg} / \mathrm{ha}$ in plots of $2.5 \times 20 \mathrm{~m}$ with four replicates. The sowing time was usually the last week of August. A compound fertilizer, $15-20-15\left(\mathrm{~N}-\mathrm{P}_{2} \mathrm{O}_{5}-\mathrm{K}_{2} \mathrm{O}\right)$ was placed into the soil before sowing at the rate of $500 \mathrm{Kg} / \mathrm{ha}$. In the spring additional

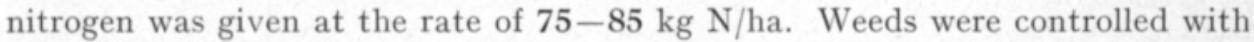
herbicidal spraying together with chlormequat-chloride treatment in the spring. The plots were harvested with a normal combine harvester during the month of August, or in some years, in late July. The presence of snowmould was observed in the spring and the density of the stands was evaluated, but no fungus species determination was made.

\section{Seedling spraying trials}

The plots for spraying trials were selected after the emergence of the rye crop. All the treatments had been seeddressed with mercury. The plot size varied in different years being usually $4 \times 30 \mathrm{~m}$ with four replicates. Avicol, a commercial quintozene wettable powder $(500 \mathrm{~g} / \mathrm{kg})$, was sprayed at the rate of $10 \mathrm{~kg} / \mathrm{ha}$ added to 4001 of water/ha with a portable Azo-Propan sprayer. When the temperature was well below freezing, warm water was used. Thiophanate-methyl was the same that was used in the seeddressing trials. Its rate of use was now $400 \mathrm{~g} / \mathrm{ha}$, also added to $400 \mathrm{l}$ of water/ha.

The timing of sprayings varied depending on the weather each autumn.

Thiophanate-methyl was usually sprayed earlier, whereas the spraying of quintozene was postponed as late as possible before the permanent snow cover. Table 1 shows the exact date and the weather conditions during the spraying each year.

Table 1. Weather conditions at the time of spraying.

\begin{tabular}{llrrl}
\hline Year & Treatment & Date & Temperature & \multicolumn{1}{c}{ Other conditions } \\
\hline \multirow{2}{*}{1973} & Quintozene & 19.12. & $-8^{\circ} \mathrm{C}$ & slight groundfrost, no snow \\
& Thiophanate & 6.10 & $+8^{\circ} \mathrm{C}$ & no groundfrost, no snow \\
\multirow{2}{*}{1974} & Quintozene & 26.11. & $-8^{\circ} \mathrm{C}$ & $10 \mathrm{~cm}$ groundfrost, $9 \mathrm{~cm}$ snow \\
& Thiophanate & 4.10. & $+12^{\circ} \mathrm{C}$ & no groundfrost, no snow \\
\multirow{2}{*}{1975} & Quintozene & 30.12. & $-4^{\circ} \mathrm{C}$ & $2 \mathrm{~cm}$ groundfrost, $1 \mathrm{~cm}$ snow \\
& Thiophanate & 10.12. & $0^{\circ} \mathrm{C}$ & no groundfrost, soil wet \\
\multirow{2}{*}{1976} & Quintozene & 17.12. & $-5^{\circ} \mathrm{C}$ & $2 \mathrm{~cm}$ groundfrost, $10 \mathrm{~cm}$ snow \\
& Thiophanate & 20.10. & $+3^{\circ} \mathrm{C}$ & no groundfrost, no snow \\
\multirow{2}{*}{1977} & Quintozene & 12.01. & $-10^{\circ} \mathrm{C}$ & $15 \mathrm{~cm}$ groundfrost, 20 cm snow \\
& Thiophanate & 23.11. & $0^{\circ} \mathrm{C}$ & no groundfrost, no snow \\
& Quintozene & 03.11. & $+1^{\circ} \mathrm{C}$ & no groundfrost, no snow \\
& Thiophanate & 18.10. & $+6^{\circ} \mathrm{C}$ & no groundfrost, soil wet \\
\hline
\end{tabular}


The fertilization, weed control, chlormequat-chloride treatment, harvest, and observations were carried out as above. During the years 1973, 1974, 1975 and 1976 the seeddressing and the seedling spraying trials were established in the same field, and therefore the yield results in the mercury seeddressing trials are identical to those of unsprayed control in the seedling spraying trials for the same years.

\section{Results}

The presence of snowmould was obvious in 1972, 1974, 1977 and 1978, but really abundant only in 1977 (Table 2.). Correspondingly, the density of the crop was also lowest in 1977. The cold and dry spring thinned down the stands in 1978, and the damage caused by snowmould alone was not very significant. There was no visible trace of the disease in 1973, 1975 and 1976.

Table 2. The density of the crop $(0-100)$ and the presence or absence of snowmould $(-=$ no snowmould, $+=$ slight, $++=$ fair, $+++=$ heavy) in the untreated and unsprayed plots at the beginning of the growth in spring.

\begin{tabular}{llrrrr}
\hline Year & \multicolumn{2}{c}{$\begin{array}{c}\text { Seeddressing trials } \\
\text { Density }\end{array}$} & \multicolumn{2}{c}{$\begin{array}{c}\text { Seedling spraying trials } \\
\text { Sensity }\end{array}$} & Snowmould \\
\cline { 1 - 3 } & & & & & \\
1972 & 93 & + & & \\
1973 & 98 & - & 100 & - \\
1974 & 73 & + & 72 & + \\
1975 & 98 & - & 100 & - \\
1976 & 92 & - & 94 & - \\
1977 & 48 & ++ & 9 & +++ \\
1978 & 69 & + & 76 & + \\
\hline
\end{tabular}

The yield results for the seeddressing trials are shown in Fig. 1. Chemical treatments gave higher yields than did the untreated crops, notwithstanding the presence or absence of the snowmould, the difference being statistically significant. There was no statistically significant difference between the two treatments, although thiophanate-methyl gave an average of $325 \mathrm{~kg} / \mathrm{ha}$ and mercury only $14 \mathrm{~kg} / \mathrm{ha}$ more yield compared to the untreated crop. The negative yield results from those years with little or no snowmould lower the mean of seven years considerably.

The yield results for seedling spraying are basically similar (Fig. 2.). On an average the yield increase is somewhat higher than that of mercury seeddressing for both spraying treatments. Thiophanate-methyl is, however, more efficient even as seeddressing than quintozene as a spraying. The highest yield increase was obtained with thiophanate-methyl-spraying, $438 \mathrm{~kg} / \mathrm{ha}$. Due to the absence of snowmould in the above mentioned years no statistically significant difference was found in the average between the sprayed and unsprayed treatments. The yield increases in other years correlate quite well with the observations of the presence of snowmould. 
YIELD

$\mathrm{kg} / \mathrm{ha}$

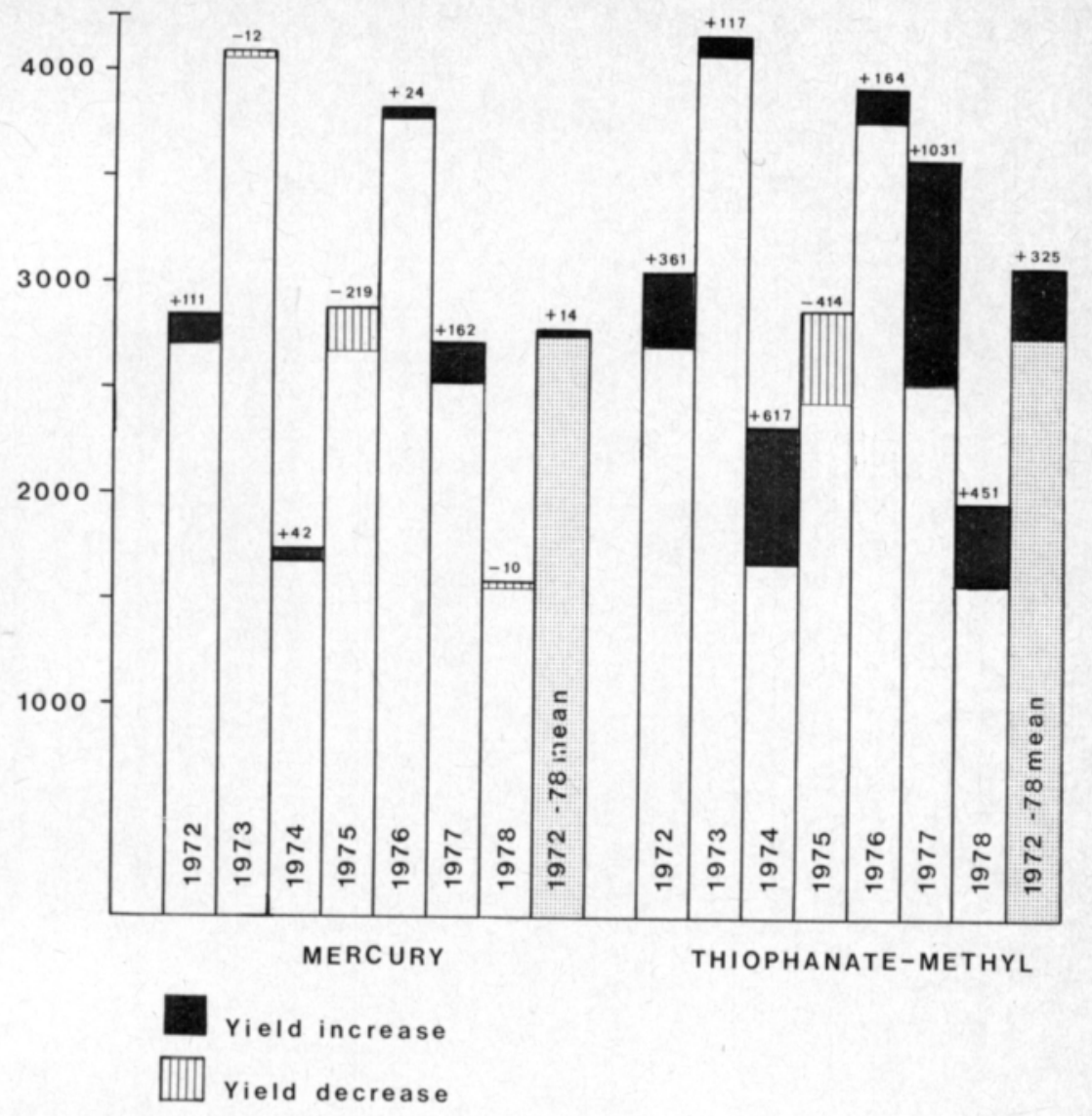

Fig. 1. Seeddressing trials in 1972-1978. The yield increase or decrease is compared to the untreated seeds (F-value 4.201*). 


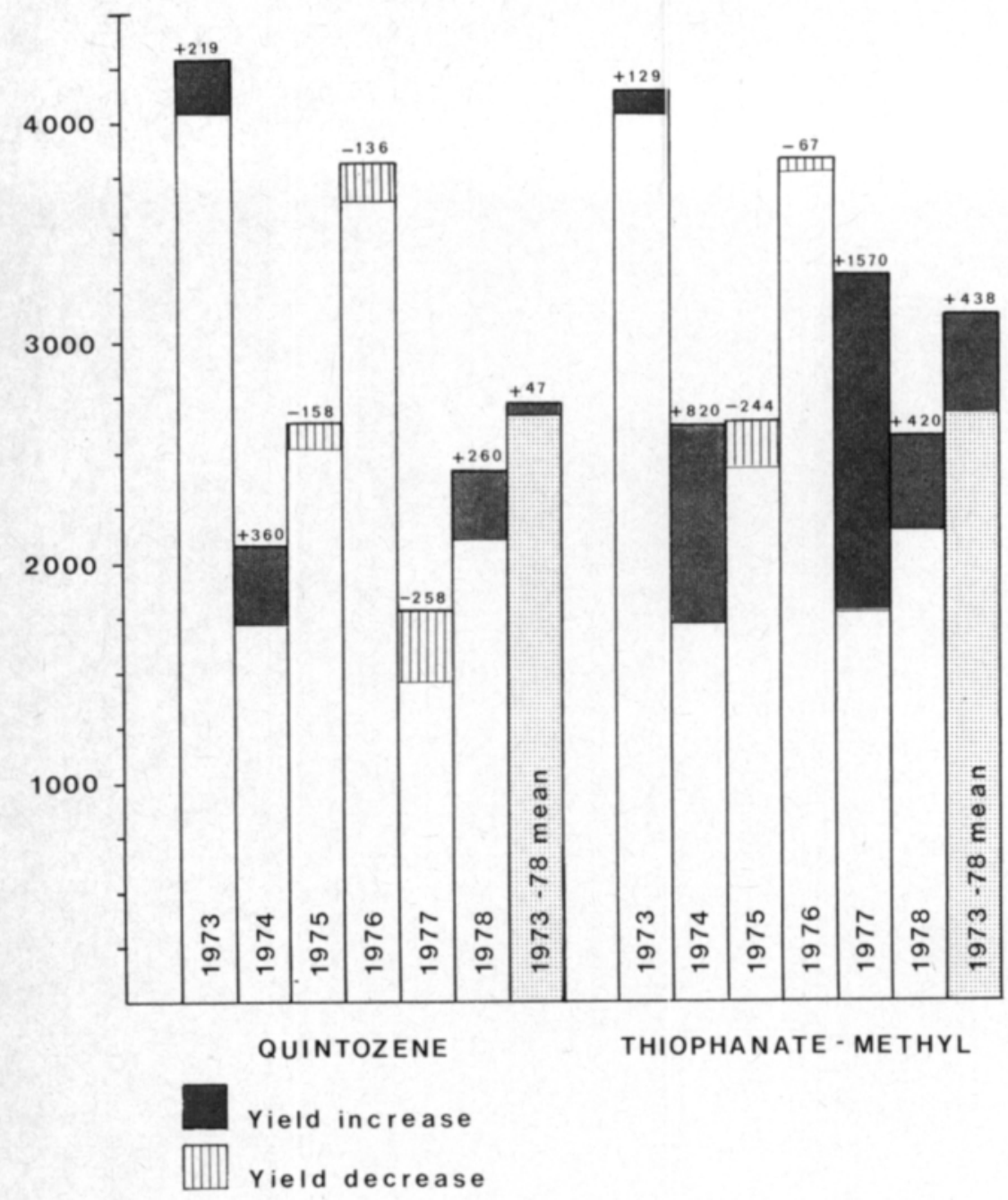

Fig. 2. Seedling spraying trials in $1973-2978$. The yield increase or decrease is compared to the unsprayed seedlings grown from the seeds treated with mercury seeddressing (F-value $1.994^{\circ}$ ).

\section{Discussion}

In both methods of protecting the crop from the overwintering damage the thiophanate-methyl gave the highest yield increase. As a systemic fungicide even as seeddressing it can obviously control some soil borne fungi. In these results it was slightly more effective as seedling spraying. The rate per hectare is the same for seeddressing and seedling spraying, and so the cost of the chemical is also equal in both methods. The additional cost of spraying, and in some years the difficulty of finding suitable weather and soil conditions for tractor spraying, can make the latter method less interesting. For better control, particularly in heavy infection which in practice is impossible to foresee, spraying would, however, seem a more reliable alternative. 
The conventional treatments, mercury seeddressing and quintozene spraying, gave a much smaller yield increase than thiophanate-methyl. The desinfective effect of mercury is not sufficient to control soil borne pathogens, and F. nivale is seldom found in the seed of cereals (YLIMÄKI 1970, UotI and YLIмÄкI 1974). However, the mercury seeddressing ensures the germination and sprouting of the seeds by controlling the other possible seed borne fungi, and it gives a good basis for later spraying treatments. Also as a very economical treatment it may always be recommended.

The rather poor results with quintozene spraying make this product less economical, since the hectare cost alone is almost double that of thiophanatemethyl. Its use in southern Finland may not be as useful as it undoubtedly is in the northern parts of the country, where, in addition to $F$. nivale, other soil borne fungi, such as Typhula-species and Sclerotinia borealis Bub. \& Vleugel, are also present (JAmalainen 1956) and their control is possible only with quintozene. The timing of the quintozene application is more difficult in the south, where the beginning of the winter is very variable and is often delayed until January. Too early a spraying of quintozene is useless because heavy rains may cause leaching and a loss of efficacy.

\section{REFERENCES:}

JAmalainen, E. A. 1956. Overwintering of plants in Finland with respect to damage caused by low temperature pathogens. Valt. Maatal.koetoim. Julk. 148: 5-30.

- 1962. Syysviljojen peittauskokeet Suomessa. Ann. Agric. Fenn. 1: 175-191.

- 1964. Control of low temperature parasitic fungi in winter cereals by fungicidal treatments of stands. Ann. Agric. Fenn. 3:1-54.

- 1969. Resistance of Scandinavian winter cereal varieties to low temperature parasitic fungi. Ann. Agric. Fenn. 8: 251-263.

MãKELĀ, K. 1978. Viljapellon maasienistō on runsaslajinen. Koetoim. ja Käyt. 35: 35.

Tirttanen, K. \& Blomovist, H. 1978. Sales of pesticides in Finland. 1977. Kemia-Kemi 10: $481-483$.

Uоті, J. \& YцгмӓкI, A. 1974. The occurrence of Fusarium species in cereal grain in Finland. Ann. Agric. Fenn. 13:5-17.

YlıмйKI, A. 1970. The microflora of Finnish cereal seeds. Ann. Acad. Sci. Fenn. A IV Biol. 168: $71-72$.

Ms received July 17,1979 


\section{Elohopean, kvintoseenin ja tiofanaattimetyylin vaikutus rukiin satoon Kotkaniemen koetilalla vv. $1972-1978$}

JUHANI UOTI

Kemira Oy, PL 330, 00101 Helsinki 10

Kemiran Kotkaniemen koetilalla Vihdissä järjestettiir. vv. 1972-1978 rukiilla talvituhosienten torjuntakokeita sekä peittauksena että orasruiskutuksena. Peittausaineina verrattiin elohopeaa (Täyssato) ja tiofanaattimetyyliä (Topsin M). Orasruiskutuskokeissa kylvösiemen oli peitattu elohopealla ja ruiskutuksissa käytettiin kvintotseenia (Avicol) tai tiofanaattimetyyliä.

Käyttömäärät peittauksessa olivat molemmilla valmisteilla $200 \mathrm{~g} / 100 \mathrm{~kg}$ siementä ja orasruiskutuksissa kvintotseeni-valmistetta käytettiin $10 \mathrm{~kg} / \mathrm{ha}$ ja vastaavasti tiofanaatti-valmistetta $400 \mathrm{~g} / \mathrm{ha}$. Kvintotseenin ruiskutusaika vaihteli siäoloista riippuen, mutta se pyrittiin suorittamaan mahdollisimman myöhään ennen pysyvää lumipeitettä. Tiofanaattimetyyli ruiskutettiin aikaisemmin, yleensä loka-marraskuussa.

Lumihometta esiintyi selvästi vain vuosina 1972, 1974, 1977 ja 1978. Runsaimmin sienituhoja oli v. 1977. Peittauskokeissa elohopean vaikutus vaihteli suuresti, keskimäärin saatiin sadonlisäystä vain $14 \mathrm{~kg} / \mathrm{ha}$. Tiofanaattimetyyli-peittaus sen sijaan antoi keskimäärin 325 $\mathrm{kg} /$ ha sadonlisäyksen. Vuonna 1975 aiheuttivat molemrnat peittauskäsittelyt sadonalennusta.

Orasruiskutuksissa tiofanaattimetyyli antoi kvintotseenia paremman tuloksen. Sen antama keskimääräinen sadonlisäys oli $438 \mathrm{~kg} / \mathrm{ha}$, kun se kvintotseenilla jäi $47 \mathrm{~kg}$ :oon/ha. Kuten peittauskokeissa orasruiskutuksissakin saatiin eräinä vuosina myös sadonalennuksia, jotka vaikuttivat myös keskimääräisiin satotuloksiin alentavasti.

Tulosten perusteella tiofanaattimetyyli antaa peittauksena paremman tuloksen kuin elohopéa. Tiofanaattimetyyli on myös ruiskutuksena parempi kuin kvintotseeni ainakin EteläSuomen oloissa, missä talvituhojen pääasiallisin aiheustaja on Fusarium nivale (Fr.) Ces. Näiden kokeiden perusteella tiofanaattimetyylillä tehty ruiskutus antoi peittausta hieman paremman sadonlisäyksen. 